\title{
FOUR BASIC SKILLS PROFICIENCY BASED ON STUDENTS' PERCEPTION IN HOSPITALITY \& TOURISM STUDY PROGRAM, BUNDA MULIA UNIVERSITY
}

\author{
Supina* \\ Hospitality and Tourism Department, Bunda Mulia University \\ Received on 1 April 2018 / Approved on 16 April 2018
}

\begin{abstract}
Wide open employment in the tourism industry leads to the urgent needs for ready to work manpower. In the tourism industry, the readiness of the workforce in addition to the operational skills of the work is the ability of foreign language that is widely used globally in the world, in this case is English. Tourism education institutions as tourism human resources factories not only must prepare operational skills, but also English skills which is important to avoid complaints from graduates' saying that educational institutions do not provide sufficient English supplies. In order to provide sufficient English supplies, student's English proficiency should be known at this time along with the reason, to know what can improve student's spirit of learning, because English for Tourism Purposes (ETP) can not be measured only by tests such as TOEFL / TOEFL / IELTS. The results of this study is expected to be a improvement material to improve the quality of every tourism student's English in order to prepare graduates who are ready to work in a Global environment.
\end{abstract}

Keywords: English for Tourism Purposes, Proficiency, Four Basic Skills

\begin{abstract}
ABSTRAK
Lapangan pekerjaan yang terbuka luas dalam industri pariwisata tentunya berdampak pada mendesaknya pemenuhan kebutuhan tenaga kerja yang siap bekerja. Dalam industri pariwisata, kesiapan tenaga kerja selain keterampilan operasional kerja, dibutuhkan keterampilan lain yaitu kemampuan bahasa asing yang banyak digunakan secara global di dunia, dalam hal ini adalah bahasa Inggris. Institusi pendidikan pariwisata sebagai pabrik sumber daya manusia pariwisata tidak hanya harus mempersiapkan keterampilan operasional, tetapi juga keterampilan bahasa Inggris. Hal ini penting untuk menghindari terjadinya keluhan dari lulusan yang mengatakan bahwa Institusi pendidikan tidak menyediakan pasokan bahasa Inggris yang cukup. Untuk menyediakan pasokan bahasa Inggris yang cukup, kemahiran bahasa Inggris mahasiswa/i saat ini harus diketahui bersama dengan alasan/motivasi belajarnya, untuk mengetahui apa yang dapat dilakukan untuk meningkatkan semangat belajar dan kemahirannya, karena English for Tourism Purposes (ETP) tidak dapat diukur hanya dengan tes seperti TOEIC / TOEFL / IELTS. Hasil penelitian ini diharapkan dapat menjadi bahan perbaikan untuk meningkatkan kualitas bahasa Inggris setiap mahasiswa/i pariwisata untuk memastikan bahwa saat mahasiswa/i lulus mampu bekerja dalam lingkungan global.
\end{abstract}

Kata Kunci: Bahasa Inggris untuk Keperluan Pariwisata, Kemahiran, Empat Keterampilan Dasar

\section{INTRODUCTION}

Tourism is one of the most powerful weapons in developing a country's economy. In Indonesia itself, tourism placed as the nation's backbone economy, Indonesia has many competitive advantages and comparative advantages. In 2019 the Tourism Industry is projected to be the largest foreign exchange earner, USD 24 Billion, beyond the oil and gas, coal and palm oil sectors. The impact of the foreign exchange is immediately felt by all levels of society (Ministry of Tourism of Indonesia, 2016)

The development of tourism industry must be balanced with the availability of the

*Author(s) Correspondence:

E-mail: supina@bundamulia.ac.id 
ready to work human resources in the field of Tourism. Until 2017, Tourism-based Education Institutions throughout Indonesia can only contribute $2 \%$ of the total workforce in the Tourism sector in Indonesia (Coordinating Ministry of Economic Affairs, 2017)

Tourism was established as an autonomous science in 2013, causing in previous years Tourism based Education Institutions are still very few. However, since 2013, many Education Institutions have begun to open a Tourism based study program, or establish a new Tourism based Education Institution.

Tourism-based education institutions are certainly responsible for producing wellprepared graduates in tourism. In addition to a range of operational skills in tourism, other skills required which are closely related to the tourism industry are language skills. In this case is the ability to speak English, which became the common language widely used in the World.

Language skills used in tourism employment practices are also very different from academic language skills, not necessarily those with good language test scores (TOEIC / TOEFL / IELTS) capable of applying the language to work in tourism operations.

A research about an evaluation of English teaching and leaning in Tourism training programs was done in Vietnam by Khuong (2015) resulted that key stakeholders held somewhat negative opinions about the English language teaching and learning in most of the tourism programs provided by the tertiary institutions examined in Vietnam. As a result, these programs produced insufficient employable students to satisfy the growing demand of international tourists.

The students' level English was evaluated as unsatisfactory in comparison with the requirements of the lecturers and companies. The students blamed the programs for not providing them with that competence. The main factors for these unexpected outcomes included inappropriate laws with regard to the issue of international tourguiding permit, unsatisfactory quality of teaching staff, an inappropriate amount of time allocated for foreign language learning in the curriculum, insufficient quality of foreign language teaching materials, inadequate opportunities for students to communicate in the target language, and ineffective assessment processes.

Hospitality and Tourism Study Program, Bunda Mulia University is a tourism-based study program in Indonesia which since its establishment in 2013 shows improvement in various aspects such as number of students, student achievement and achievement of Study Program Accreditation. In 2018, the Hospitality and Tourism Study Program graduates its students for the first time with the absorption of more than $70 \%$ of students working before graduation. And from $70 \%$ of the students who have worked, the feedback data processing from graduate users says that $70 \%$ students' English skills are excellent and $20 \%$ good, only $10 \%$ have enough English skills. Meanwhile, when students do On The Job training still get many input which said that students can actually use English but still shy.

To ensure that the results of research in Vietnam where students blame the study program because they are not giving enough teaching and learning in language skills would not happen. It is necessary to research about Four Basic Skills Proficiency based on Students' Perception in Hospitality \& Tourism Study Program, Bunda Mulia University which is the basis of the ability of English for Tourism Purposes (ETP).

\section{LITERATURE REVIEW}

\section{The Four Basic Skills}

Language educators have long used the concepts of four basic language skills: Listening, Speaking, Reading, Writing. These four language skills are sometimes called the "macro-skills". This is in contrast to the "micro-skills" such as grammar, vocabulary, pronunciation and spelling. The four basic skills are related to each other by two parameters: the mode of communication: oral or written and the direction of communication:

\footnotetext{
*Author(s) Correspondence:

E-mail: supina@bundamulia.ac.id
} 
receiving or producing the message. Listening comprehension is the receptive skill in the oral mode. When we speak of listening what we really mean is listening and understanding what we hear. Listening comprehension is the receptive skill in the oral mode. When we speak of listening what we really mean is listening and understanding what we hear. Speaking is the productive skill in the oral mode. It, like the other skills, is more complicated than it seems at first and involves more than just pronouncing words. Speaking is often connected with listening. For example, the two-way communication makes up for the defect in communicative ability in the traditional learning. Temple and Gillet (1984) as cited in Aydoğan \& Akbarov (2014) also emphasize the close relationship between listening and speaking in this way.

Reading is the receptive skill in the written mode. It can develop independently of listening and speaking skills, but often develops along with them, especially in societies with a highly-developed literary tradition. Reading can help build vocabulary that helps listening comprehension at the later stages, particularly. Writing is the productive skill in the written mode. It, too, is more complicated than it seems at first, and often seems to be the hardest of the skills, even for native speakers of a language, since it involves not just a graphic representation of speech, but the development and presentation of thoughts in a structured way (Aydoğan \& Akbarov, 2014)

\section{English for Specific Purposes (ESP)}

Mackay and Mountford (1978) as cited in Lamri (2016) stated that "ESP is generally used to refer to the teaching of English for a clearly utilitarian purpose." That is to say that English should be taught to achieve specific language skills using real situations, in a manner that allows them to use English in their future profession, or to comprehend English discourse related to their area of speciality. Generally, the students study English "not because they are interested in the English Language or English culture as such, but because they need English for study or work purposes" (Robinson, 1991 as cited in Lamri, 2016). In ESP, "language is learnt not for its own sake or for the sake of gaining a general education, but to smooth the path to entry or greater linguistic efficiency in academic, professional or workplace environments" (Basturkmen, 2006 as cited in Lamri 2016). This denotes that, the role of ESP is to help language learners to build up the needed abilities in order to use them in a specific field of inquiry, occupation, or workplace. These definitions were stated according to ESP evolution through time, this latter is viewed in more details in the following section.

\section{English for Tourism Purposes (ETP)}

According to Leslie \& Russell (2006) as cited in Zahedpisheh, Bakar, and Saffari (2017), being skillful in foreign language skills is necessary for people working in the tourism and hospitality sector. The reason is that it is the means for having communication with foreign tourists and understanding cultural differences. In fact, for those who are seeking employment in the tourism, hospitality and service industry, it is essential to stay highly motivated in order to be accurately fluent in a high level of professional service language. In fact, they are required to become proficient in English for Tourism Purposes (Cravotta, 1990 as cited in Zahedpisheh, Bakar, \& Saffari, 2017).

Moreover, Cho (2005) as cited in Zahedpisheh, Bakar, \& Saffari (2017) believes that English for tourism is viewed as an area of business English and incorporate business English and English for academic purposes by bridging workplace communication and classroom use. This can help to increase the job opportunities in the international industry. English for tourism is known as one of the attractive subjects since many of the people will be a tourist at least once in their lifetime. Moreover, learning English for tourism purposes is crucial for those who are working in guest-host relation section such as hotels, travel agencies, restaurants, information centres and tourist attractions. In industrial sectors, English has recently become a core

\footnotetext{
*Author(s) Correspondence:

E-mail: supina@bundamulia.ac.id
} 
subject, and hospitality training programs help the employees achieve English proficiency to fulfil the job responsibilities (Hsu, 2010; Chen, Chiu, \& Lin, 2011; Kuppan, 2008 as cited in Zahedpisheh, Bakar, \& Saffari, 2017).

According to Buhler (1990) as cited in Zahedpisheh, Bakar, \& Saffari, 2017), English for tourism is comparable to other languages and can be examined by principal properties such as functions, structures, and tenses. In fact, English for tourism is a structured language and follows definite grammar rules. Dann (2001, as cited in Zahedpisheh, Bakar, \& Saffari, 2017) states that the vocabulary used in the English for tourism is special and conveys messages through a conventional system of symbols and codes. For instance, the language used for checking into a hotel, giving information about hotel facilities, meal times, giving directions, requesting and giving tourist information, and other communicative activities that can take place in any hospitality setting. Strutt (2003) as cited in Zahedpisheh, Bakar, \& Saffari, 2017), in his introduction, describes his textbook (English for International Tourism) as needing no specialized knowledge 'it is not technical or over-specialized in nature.' In fact, ESP textbooks are significantly similar to any general English textbook. For instance, grammar in these books is used as a means of structure. However, all the examples are used within the tourism, medicine, or business context make a distinction from a usual ELT textbook (Brieger \& Sweeney, 1994 as cited in Zahedpisheh, Bakar, \& Saffari, 2017).

\section{The Study of Communication Instead of Language}

Clearly English for Specific Purposes (ESP) has moved some way from its original exclusive focus on text features. In the past, materials were often based solely on the lexical and grammatical characteristics of scientific and business discourses in isolation from their social contexts. Today these materials have largely been replaced by those that acknowledge wider interactional and semiotic contexts, where language and tasks are more closely related to the situations in which they are used. ESP practitioners now address wider communicative skills in their teaching. In the area of research, ESP attempts to go beyond texts to understand how they work in particular disciplines or professions, seeing genres, for instance, as recognizable kinds of social activity embedded in particular kinds of interaction rather than just arrangements of forms (Hyland, 2007).

To understand language and the functions it performs for people, we have to appreciate how it is used within particular contexts, identifying the purposes and participants that are integral to the construction of particular communicative processes and products. We need, for instance, to understand the interpersonal conventions a sales manager might observe when giving a client presentation or the knowledge a chemist assumes of his or her audience when writing up a lab report. In the classroom, these concerns translate into finding ways of preparing students to participate in a range of activities and to see ESP as concerned with communicative practices rather than more narrowly with specific aspects of language (Hyland, 2007).

\section{RESEARCH METHODOLOGY}

The research design used is Descriptive Design and Correlational, which aims to see the relationship between two variables. Correlation does not guarantee the existence of causality (causality), but causality ensures correlation. The research location is Bunda Mulia University, Jakarta. The study was conducted from January to May 2018.

The total population of Hospitality and Tourism Study Program, Bunda Mulia University is approximately 590 students. As for the sample, Malhotra (as cited in Husein, 2003) mentions that for descriptive and quantitative research, the required number of samples is 100 units. By following these guidelines, the study used 115 respondents as samples.

Respondents asked to fill out equestionnaire that is given to them and filled directly. The respondents remain completely

\footnotetext{
*Author(s) Correspondence:

E-mail: supina@bundamulia.ac.id
} 
anonymous. The measurement measured here is based on a measurement held by Bobanovic and Grzinic (2011), but on this research there is no comparative study. The questionnaire was divided into four sections according to the traditional four skills (reading, writing, listening, and speaking) and one general question's sections. Respondents were asked to choose the most appropriate answer.

\section{FINDINGS AND DISCUSSION}

\section{Respondents' Socio-Demographics}

Table 1. Respondents' Gender

\begin{tabular}{|c|c|c|}
\hline Gender & No of Respondents & \% of Respondents \\
\hline Male & 45 & $60,9 \%$ \\
\hline Female & 70 & $39,1 \%$ \\
\hline
\end{tabular}

Table 2. Respondents' History of English Learning

\begin{tabular}{|c|c|c|}
\hline $\begin{array}{c}\text { Did they ever take an } \\
\text { English course? }\end{array}$ & No of Respondents & \% of Respondents \\
\hline Yes & 84 & $73 \%$ \\
\hline No & 31 & $27 \%$ \\
\hline
\end{tabular}

Table 3. Respondents' Semester

\begin{tabular}{|c|c|c|}
\hline Semester & No of Respondents & $\%$ of Respondents \\
\hline 2 & 84 & $73 \%$ \\
\hline 4 & 31 & $27 \%$ \\
\hline
\end{tabular}

\section{Respondents' Perception on Reading}

Chart 1. Reasons/Motives for Reading in English

\begin{tabular}{|c|c|c|c|c|}
\hline \multicolumn{5}{|c|}{$\begin{array}{c}\text { Reasons/Motives for Reading } \\
\text { English }\end{array}$} \\
\hline $7,80 \%$ & $13,90 \%$ & & $3,60 \%$ & $10,40 \%$ \\
\hline $\begin{array}{c}\text { Edu Non } \\
\text { Operational }\end{array}$ & $\begin{array}{c}\text { Edu } \\
\text { Operational }\end{array}$ & $\begin{array}{l}\text { Fun (Music, } \\
\text { Movie, Fiction } \\
\text { Book, Surfing } \\
\text { on the } \\
\text { Internet) }\end{array}$ & $\begin{array}{l}\text { Update to the } \\
\text { overseas news }\end{array}$ & $\begin{array}{l}\text { Not reading } \\
\text { any english's } \\
\text { books }\end{array}$ \\
\hline
\end{tabular}

*Author(s) Correspondence:

E-mail: supina@bundamulia.ac.id 
Above chart showed us why the respondents read in English, mostly is because they want to have fun through music, movie, fiction book, and surfing on the Internet. But sadly only $7,80 \%$ respondents read English to read Educational literature (Non Operational), and $13,90 \%$ respondents read English to read Educational literature (Operational) whereas the majority of tourism books use English.

Chart 2. Parts of English Reading Respondents Find Most Difficult to Understand

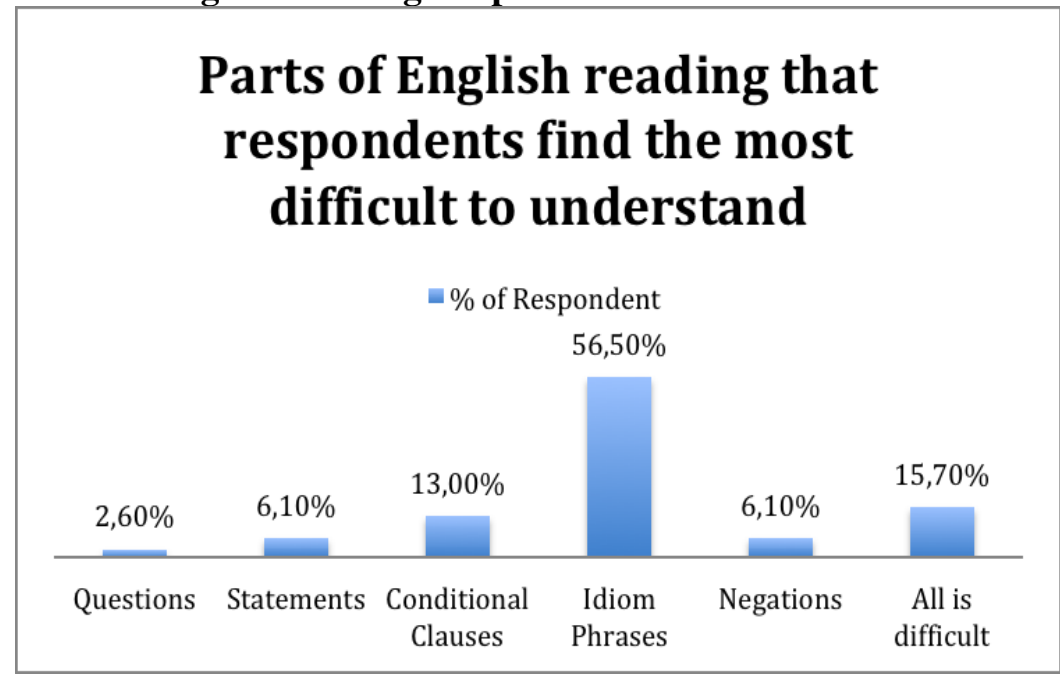

Idiom phrases become the main reason why reading English becomes difficult to understand with $56,5 \%$ or more than half of respondents. The second reason is because they just think that all parts of reading is just difficult with $15,70 \%$.

\section{Respondents' Perception on Writing}

Chart 3. Reasons / Motives for Writing in English

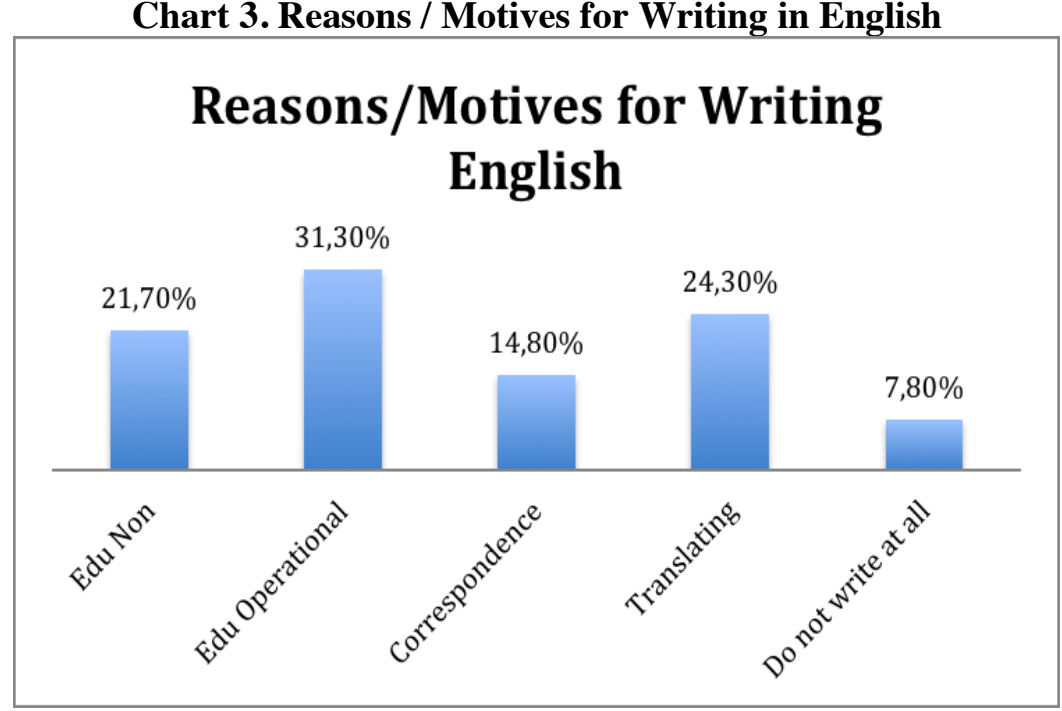

*Author(s) Correspondence:

E-mail: supina@bundamulia.ac.id 
As the respondents are active tourism students, $59 \%$ of respondents write English for educational purposes, $21,70 \%$ is writing for non operational education purposes and $31,30 \%$ is writing English for operational education purposes. Meanwhile another reasons/motives for writing English are Correspondence and Translating which may also relate to education process held in study program where the research took place. Only $7,80 \%$ respondents said they do not write English at all.

\section{Chart 4. Respondents' Opinions on the Most Difficult Part in Writing in English}

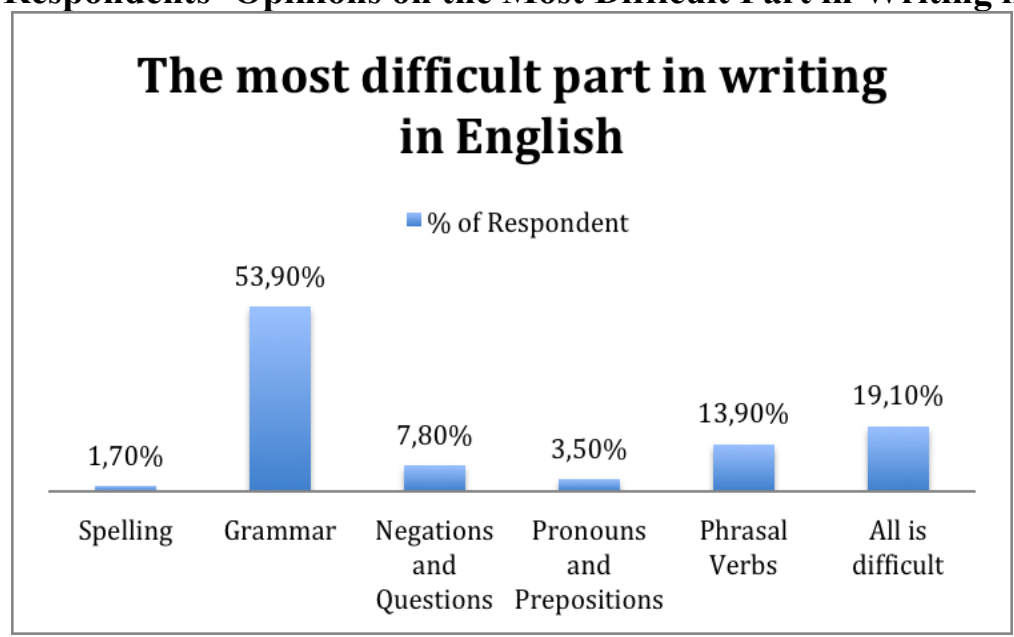

Grammar becomes the most difficult part in writing English with 53,90\%, 13,90\% respondents said that Phrasal Verbs is difficult. $7,80 \%$ respondents chose Negations and Questions as the most difficult part, 3,50\% other respondents chose Pronouns and Prepositions, while $1,70 \%$ respondents chose spelling. And 19,10\% respondents said that all parts of writing English is difficult.

\section{Respondents' Pereption on Speaking}

Chart 5. Reasons/Motives for Speaking in English

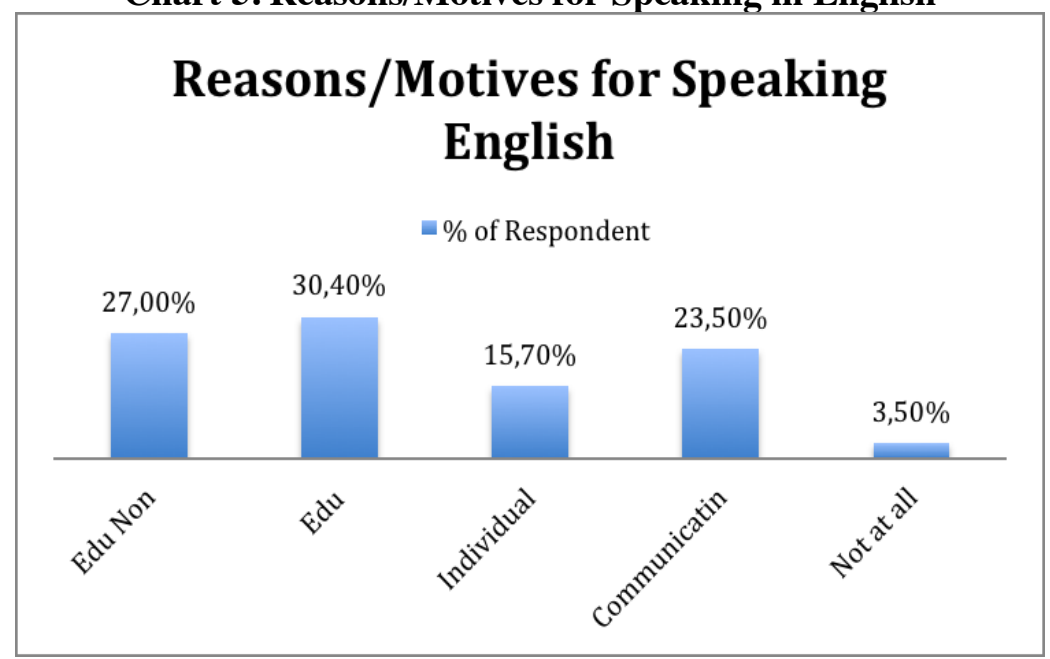

*Author(s) Correspondence:

E-mail: supina@bundamulia.ac.id 
Speaking English for operational in tourism education purposes becomes major reasons/motives in speaking English with $30,40 \%$ of the respondents, meanwhile speaking English for non operational in tourism education purposes selected by $27 \%$ of respondents. Usage of speaking English to communicate with others had 23,50\%, Individual studying with audio had $15,70 \%$ and only $3,50 \%$ of respondents said the have no reasons/motives for speaking English.

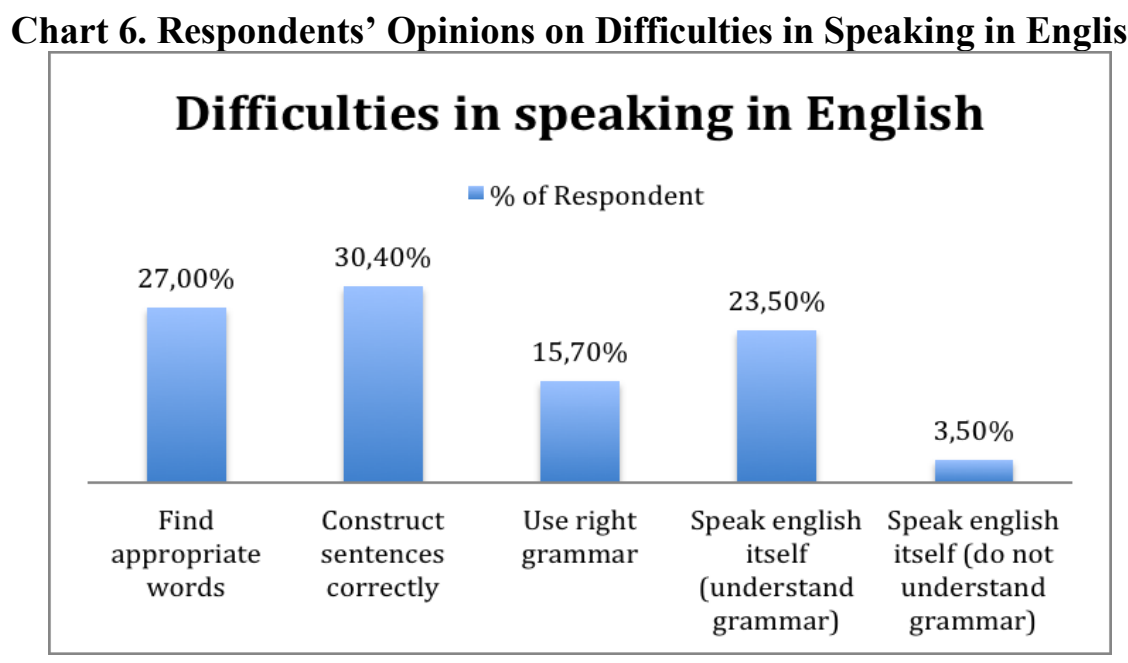

It is quite surprising that there is $23 \%, 50$ had difficulties in speaking in English even-tough they understand grammar. While another $73,10 \%$ respondents are striving in speaking in English with the right ordinance, there is $3,50 \%$ of respondents who had difficulties because they do not understand grammar.

\section{Respondents' Perception on Listening}

Chart 7. Reasons/Motives for Listening in English

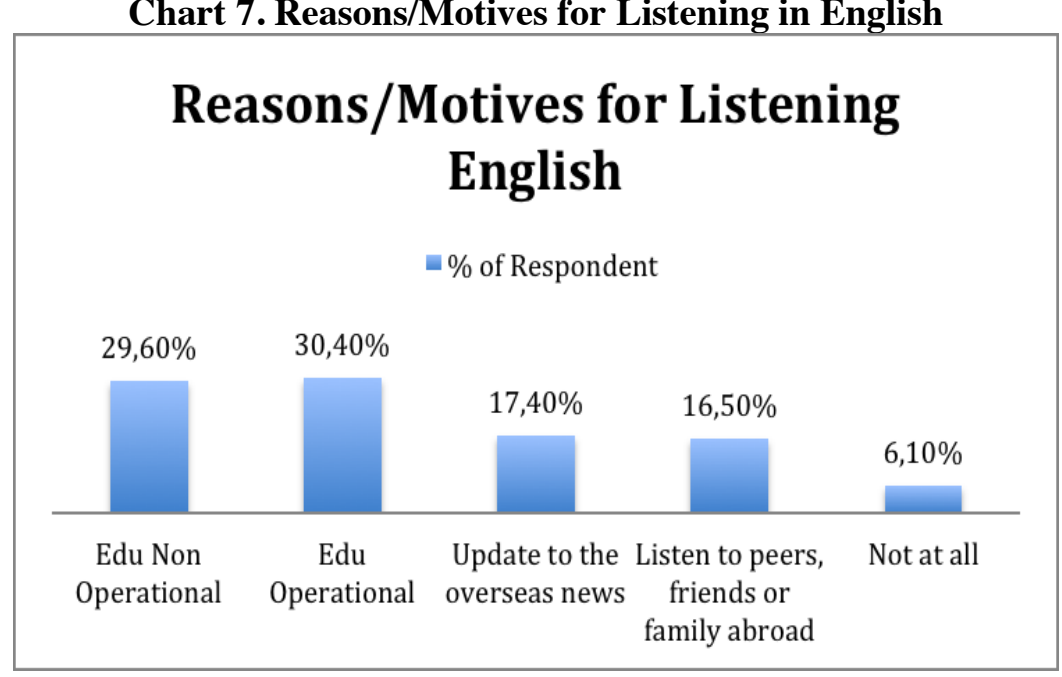

*Author(s) Correspondence:

E-mail: supina@bundamulia.ac.id 
Except for the reasons/motives in reading English. Education reasons/motives both for Tourism operational and Tourism Non Operational learning purposes become the major reason why respondents write, speak, and now listen as 60\% respondents had education as their reason in listening English. This shows that the learning process conducted in the study program where the research conducted implementing education with the use of good English, thus honing students to have three basic English skills.

\section{Chart 8. Respondents' Opinions on the Biggest Obstacles in Understanding English When Listening}

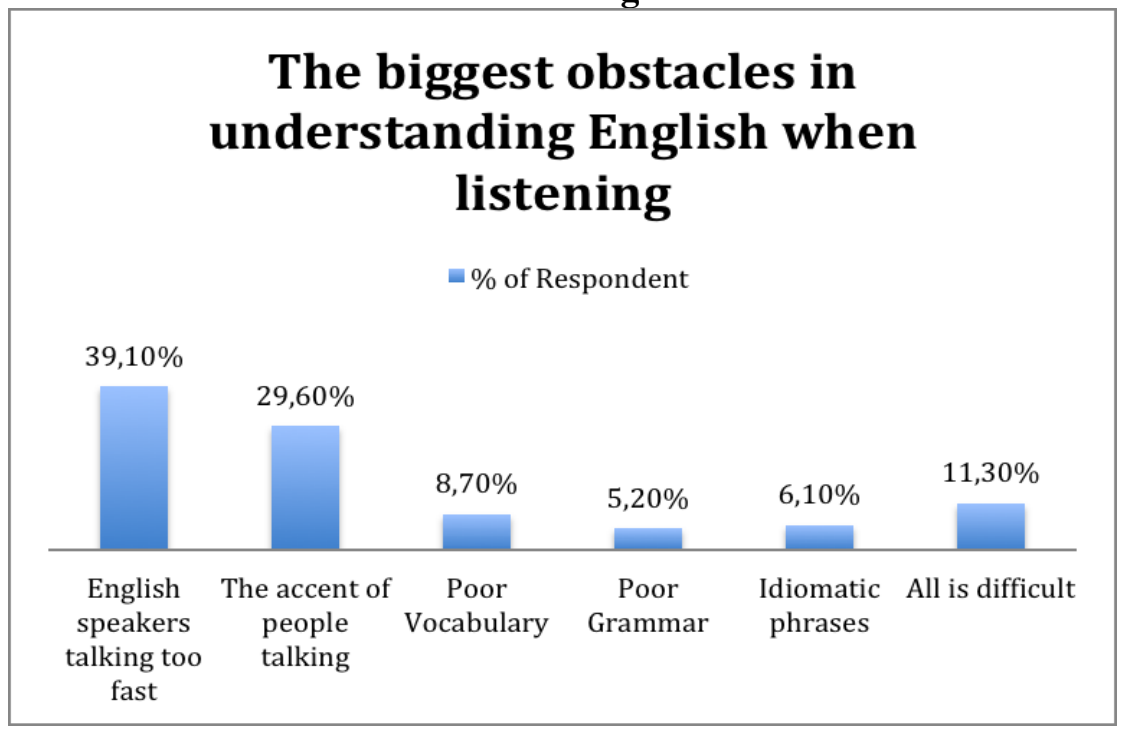

The above chart showed that Vocabulary, Grammar, and Idiomatic Phrases are not the biggest obstacles in understanding English when Listening, but English speaker who talks too fast is become the biggest obstacle with
$39,10 \%$ of respondents. $29,60 \%$ respondents feel hard to understand English when listening because of the accent of people who talks. And only $11,30 \%$ said all parts of listening in English is difficult.

\section{Respondents' Perception on Overall English Skills}

Chart 9. Respondents' Perception on Overall English Skills

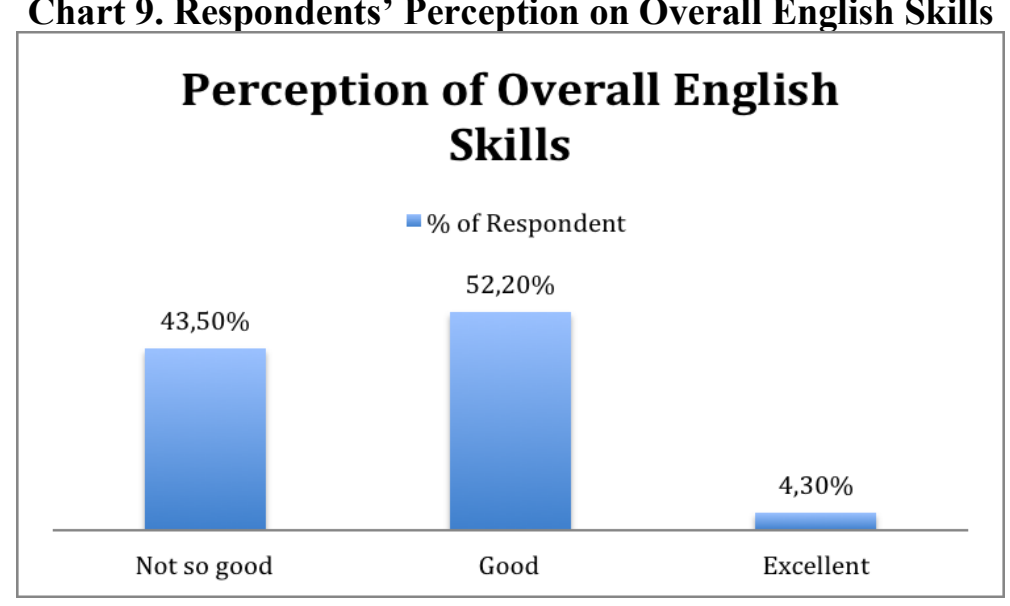

*Author(s) Correspondence:

E-mail: supina@bundamulia.ac.id 
Unfortunately, only $4,30 \%$ of respondents said that they have excellent English, 52,20\% respondents said their
English is Good and 43,50\% said that their English is not so good.

\section{Respondents' Perception on English Courses Provided by Study Program}

More than half of the respondents said that the number of credits of English courses provided is adequate, $17,40 \%$ of respondents said that it is more than adequate, and 23,50 of respondents said that the number of credit of English courses is still inadequate.

\section{Chart 10. Respondents' Perception on the Number of Credits of English Courses}

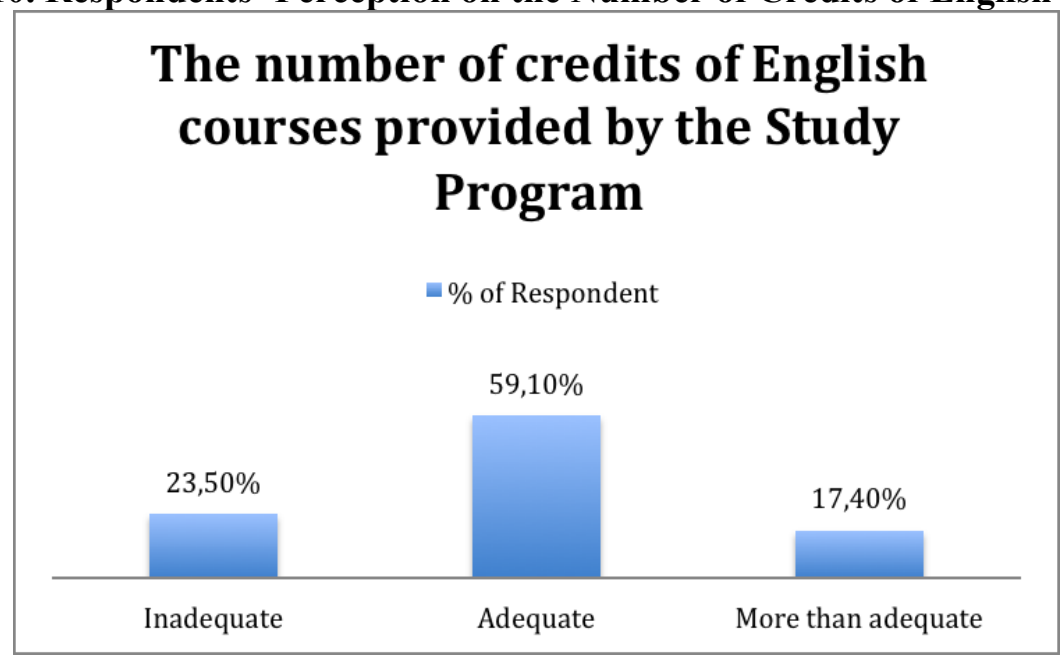

Chart 11. English Application of English-Speaking Lecturers Who Teach in English Courses

\section{English application of English speaking lecturers who teach you in English courses}

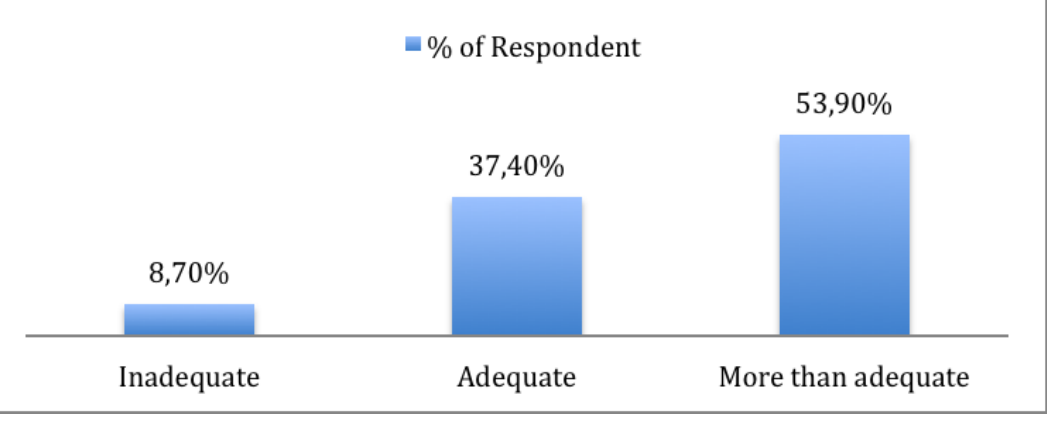

Only $8,70 \%$ of respondents said that the English application of English speaking lecturers in English courses is inadequate. It is just minority of the respondents as $53,90 \%$

*Author(s) Correspondence:

E-mail: supina@bundamulia.ac.id 
respondents said the English application is more than adequate and $37,40 \%$ said adequate.

On the other hand, even tough the operational tourism lecturer did not have any formal education in English but respondents said that English application of English speaking lecturers for Non-English courses (Operational) is $50,40 \%$ adequate, $40 \%$ more than adequate. And only $9,60 \%$ said that the English application is still inadequate.

\section{Chart 12. English Application of English-Speaking Lecturer Who Teach Non-English Courses/Operational Courses}

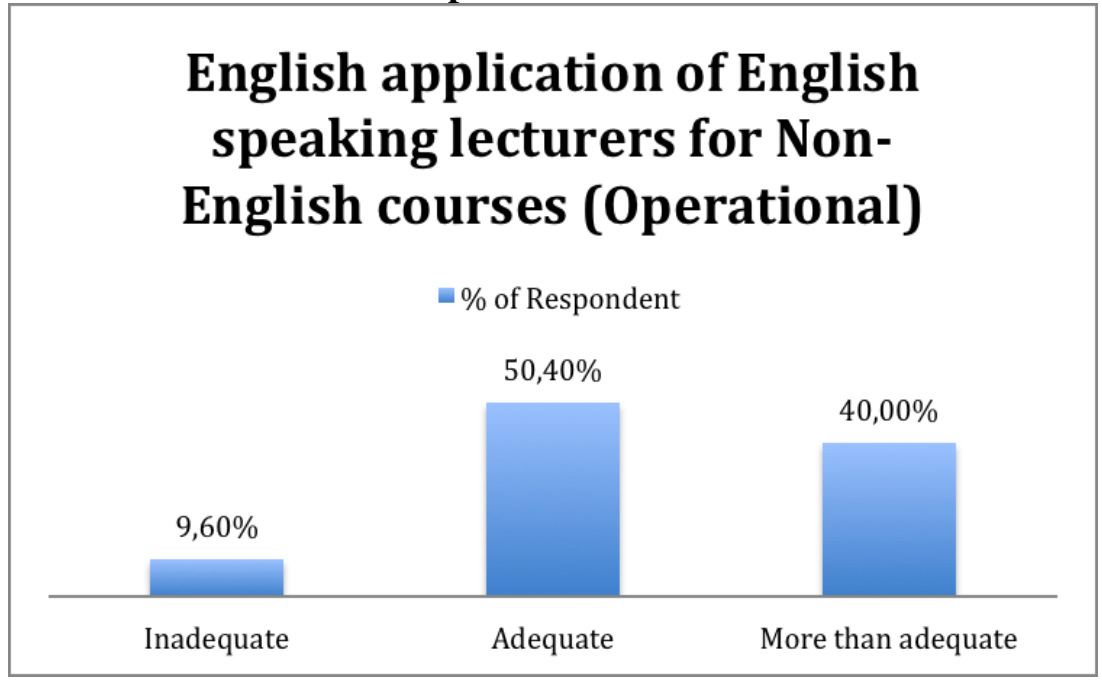

\section{CONCLUSION AND SUGGESTIONS}

In terms of reading, respondents have the major reasons/motives to read in English for Fun (Music, Movie, Fiction Book, and Surfing on the Internet), and Part of reading in English that they find the most difficult to understand is about Idiom Phrases. In terms of writing, respondents have the major reasons/motives to write in English for Education in operational studies, and Part of writing in English that they find the most difficult to do is Grammar. In terms of speaking, respondents have the major reasons/motives to speak in English for Education in operational studies as well as writing in English's reasons/motives, and Part of speaking in English that they find the most difficult to do is Grammar as well. In terms of listening, respondents have the major reasons/motives to speak in English for Education in operational studies as well as reading and writing in English's reasons/motives, and part of listening in
English that they find the most difficult to do is that English speakers tend to talk too fast.

$4,30 \%$ of respondents said that they have excellent English, 52,20\% respondents said their English is Good and 43,50\% said that their English is not so good. The result shown at provision of English language that has been prepared by study program shows that study program already gave adequate and more than adequate English language provision.

For future research, it is necessary to study the students' English proficiency from the point of view of graduate users. Meanwhile, for the study program and the academic institutions, it is necessary to socialize the understanding that English for Tourism Purposes (ETP) is different from the English for Academic Purposes (EAP), which in English for Tourism Purposes (ETP) grammar is important but not everything. Moreover, it is necessary to add the provision of English language even though the respondent said that the provision given by the

*Author(s) Correspondence:

E-mail: supina@bundamulia.ac.id 
study program is enough. But looking at the overall English skills assessment there are still $43.5 \%$ of respondents who said that their English is not good enough. Finally, it is necessary to take corrective action to overcome the problems faced by students in mastering four basic skills in English.

\section{REFERENCES}

Aydoğan, H., \& Akbarov, A. A. (2014). The four basic language skills, whole language, \& intergrated skill approach in mainstream university classrooms in Turkey [PDF File]. Retrieved February 8, 2018 from https://www.researchgate.net/publicatio n/262032435_The_Four_Basic_Langua ge Skills Whole Language Intergrated Skill_Approach_in_Mainstream_Univ ersity_Classrooms_in_Turkey.

Bobanovic, M. K., \& Grzinic, J. (2011). The importance of English language skills in the tourism sector: A comparative study of students/employees perceptions in Croatia. Almatourisam-Journal of Tourism, Culture and Territorial Development, 1, 10-23.

Coordinating Ministry of Economic Affairs. (2017). Roadmap industrialisasi pariwisata Indonesia 2045. Jakarta: Coordinating Ministry of Economic Affairs.

Hyland, K. (2007). English for specific purposes $\quad$ PDF File]. Retrieved
February $\quad 8, \quad 2018$ from https://www.researchgate.net/publicatio n/226497899_English_for_Specific_Pur poses.

Khuong, C. T. H. (2015). An evaluation of English Teaching and Learning in Tourism Training Programs in Vietnam. International Journal of Arts and Sciences, 8(6), 561-572.

Lamri, C. E. (2016). An introduction to English for Specific Purposes (ESP) [Online lectures for $3^{\text {rd }}$ Year 'License' Level]. University of Abou Bekr Belkaid Tlemcen, Faculty of Arts and Languages Department of English. Retrieved February 7, 2018 from https://faclettre.univtlemcen.dz/assets/uploads/DOCUMENT S/cours\%20en\%20ligne/4-

An\%20Introduction\%20to\%20ESP\%20 LAMRI.pdf.

Ministry of Tourism of Indonesia. (2016). Ministry of Tourism's performance report. Jakarta: Ministry of Tourism of Indonesia.

Umar, H. (2003). Metodologi penelitian untuk skripsi dan tesis bisnis. Jakarta: PT. Gramedia Pustaka.

Zahedpisheh, N., Bakar, Z. B. A., \& Saffari, N. (2017). English for Tourism and Hospitality Purposes (ETP) [PDF File]. English Language Teaching, 10(9), 8694. Retrieved February 10, 2018 from https://files.eric.ed.gov/fulltext/EJ11515 26.pdf.

*Author(s) Correspondence:

E-mail: supina@bundamulia.ac.id 